\title{
Research progress and prospects of coal petrology and coal quality in China
}

\author{
Yuegang Tang ${ }^{1}$ (D) $\cdot$ Ruiqing $\mathrm{Li}^{1} \cdot$ Shaoqing Wang ${ }^{1}$
}

Received: 30 July 2019/Revised: 24 December 2019/Accepted: 9 April 2020/Published online: 8 May 2020

(C) The Author(s) 2020

\begin{abstract}
Clean utilization of coal depends on the quality of raw coal, which depends on the coal-forming parent materials (petrology and chemical composition of coal), the multiple media of the coal-forming environment, and some epigenetic conditions, such as thermal evolution (coalification), magmatic hydrothermal fluid, groundwater. Based on the research results of predecessors and prediction studies of coal resources since the founding of China, the present status of research on coal petrology, coal quality, coal metamorphism, and coal geochemistry in China is discussed in detail, with emphasis on research progress and the general situation of highly efficient and clean utilization of coal in the technical fields of coking, pyrolysis, combustion, gasification, and liquefaction, and the development prospects of coal petrology and coal quality in China are prospected.
\end{abstract}

Keywords Coal petrology $\cdot$ Coal quality $\cdot$ Coal metamorphism $\cdot$ Coal geochemistry $\cdot$ Research status $\cdot$ Prospect

\section{Introduction}

In order to find out the real situation of Chinese coal resources, China has conducted three national coal resources prediction studies under the leadership of the Ministry of Coal Industry since the founding of New China. From 1958 to 1959, the Ministry of Coal Industry organized the first national coal prediction study. From 1973 to 1980 , the second national coalfield prediction study was organized, and "China Coalfield Geology" was compiled by scientific research institutes and universities (Yang 1979; Han 1980). The third coalfield prediction study was carried out in 1992-1997; China National Administration of Coal Geology (CNACG) compiled and published "China Coal Quality Review" (Yuan 1999) and "China Coal Resources Prediction and Evaluation" (Mao and Xu

Yuegang Tang

tyg@vip.163.com

1 College of Geoscience and Surveying Engineering, China University of Mining and Technology (Beijing), Beijing 100083, China
1996). Ministry of Geology and Mineral Resources of China also carried out a national coal prospect prediction study from 1982 to 1988 and published "Coal Petrology and Quality Characteristics and Metamorphic Rules of Chinese Coal" (Li 1997). From 2007 to 2013, CNACG undertook a study of the national coal resources potential evaluation (commonly known as the fourth coalfield prediction study), and China University of Mining and Technology (Beijing) participated in the work of the expert group as a technical support unit. In addition, two smallscale national coalfield prediction studies were carried out by the Ministry of Coal Industry in 1966-1967 and the Ministry of Geology and Mineral Resources of China in 1959-1960 (Hu et al. 2012), and Yang (1987) compiled "Coal Geology Progress". In 1996, in order to meet the 30th World Geological Congress held in Beijing, Academician Han (1996) edited "Coal Petrology of China", Academician Yang (1996a) edited "The Coal Metamorphism in China", CNACG edited "Atlas for Coal Petrography of China" (Yang 1996b), and Chen (1996) edited "Coal Petrologic Atlas of China". The above monographs reflect the achievements in coal petrology, coal quality, and 
coal metamorphism in China at the end of the twentiethcentury. In the twenty-first-century, in response to research on coal conversion and the utilization of modern technology, Bai and Ding (2016) compiled and published "Modern Coal Quality Technology". In 2016, CNACG (2016) compiled "China Occurrence Regularity of Coal Resources and Resource Evaluation", which is based on the research results of the major project "National Coal Resources Potential Evaluation of China".

\section{Research status of coal petrology in China}

\subsection{Overview of research status of coal petrology}

The study on coal petrology in China began in 1930s and has a history of nearly 100 years. From 1926 to 1949, it was the pioneering period of coal petrology in China. Since the founding of China, China's coal petrology has been growing steadily until the 1980s. In the 1990s, great progress was achieved in the study on coal petrology in China. In the twenty-first century, the development of coal petrology in China has reached a new stage. Chinese lithotype classification still uses the categorization of coal according to lustre of the Soviet Union, but there are many special coal species in China.

(1) Tectonically deformed coal. According to the complex and multi-period geological structure of China, tectonically deformed coal was specially defined. The Standardization Administration of China made the "Classification of Coal-body Structure" standard to categorize coal into original structural coal, tectonically crushed coal, granulated coal, and mylonitic coal (GB/T 30050-2013). Jiang et al. (2016) summarized the classification and expounded the characteristics of tectonically deformed coal.

(2) Sporinite liptobiolith coal. Dai et al. (2006a) found sporinite liptobiolith at Luquan, Yunnan Province. The coal had high contents of cutinite and microsporinite and were classified as cutinitic liptobiolith, sporinite-rich durain, cutinite-rich durain, and sporinitic liptobiolith.

(3) Sphagnum coal. Coal petrology and palaeobotany scholars discovered a special coal species in Yunnan Province, Sphagnum coal (named the "white-light coal" by local people) and explored its origins (Lu and Zhang 1986, 1988; Qi et al. 1994; Wang et al. 1997). Its rank could be considered as soft brown coal. For this coal, two varieties of maceral were brought forward as a complement to the ICCP's maceral classification of brown coal and lignite: sphagnum textinite and sphagnum fusinite.
(4) Chinese sclerotia-algal coal. Xie et al. (2001) classified the origins of Chinese sclerotia-algal coal. The results showed that there were obvious differences in physical and chemical composition and characteristics between sclerotia-algal coal and humic coal. The forming environment of sclerotiaalgal coal was mainly controlled by $\mathrm{pH}$, Eh value and organic matter content.

(5) Bark coal (barkinite). Barkinite was proposed by the Standardization Administration of China in 1991, but has not been recognized by the International Committee for Coal and Organic Petrology (ICCP) and The Society for Organic Petrology (TSOP), and there are many scientific problems that have not been resolved (Hower et al. 2007; Tang et al. 2011). The earliest study of bark coal in China was conducted by the coalfield geologist Hsleh (1933), followed by Han et al. (1983), Guo et al. (1996), Zhong and Smyth (1997), Sun (2001, 2002), Sun and Horsfield (2005), Tang et al. (2011), Jiao et al. (2012) and Wang et al. (2014, 2015, 2018a). "The Nature and Transformation of Bark Coal" compiled by Wang et al. (2018b), which systematically discussed the petrological characteristics of bark coal (barkinite) and rational utilization approaches.

There are several important events about the classification of macerals in Chinese coal. In the 1980s, liptohuminite was categorized according to the classification scheme of peat and soft brown coal macerals (Jin and Qin 1989). In the 1990s, semi-vitrinite and barkinite were classified according to "Classification of Macerals for Bituminous Coal", and lepidophyte-fusinite, psaroniusfusinite, and other maceralswere identified in coal (GB/T 15588-1995). Compared with the international classification scheme, semi-vitrinite was classified as vitrinite by "Classification of Macerals for Bituminous Coal" in 2001(GB/T 15588-2001), and macrinite was divided into macrinite 1 and macrinite 2 in 2013 (GB/T 15588-2013). In the 1990s, meta-exinite, meta-vitrinite, meta-inertinite, and the other new macerals were divided according to the classification of macerals of high-rank coals in China (Qin 1994). Li et al. (2000), Chen (2007), and Chen and Ma (2002) summarized and analyzed the distribution characteristics of coal macerals in Chinese coal mines based on "China Coal Resource Database".

\subsection{Geological application of coal petrology}

\subsubsection{Coal facies}

Tang et al. (2001) used coal facies parameters to analyze the relationship between the coal-forming 
microenvironment and sulfur in coal, it was found that the characteristics of water medium played a leading role in many factors controlling the microenvironment of marshes. Dai et al. (2007) performed a coal facies study to determine the enrichment facies of gallium and its carrier boehmite in coal. Mao et al. (2011a) combined sequence stratigraphy, coal facies, and coal petrology to discuss the sections change of coal sequence, coal facies, and coal petrology, which enriched the coal-forming theory. Shao et al. (2009, 2017) discussed the research status on coal facies and sedimentary organic facies in Chinese coal measures.

\subsubsection{Tectonically deformed coal}

The earliest classification of tectonically deformed coal was discussed by Chen et al. (1989a). Su and Fang (1998) divided tectonically deformed coal into four types. Ju et al. (2004) classified tectonically deformed coal into three series and ten categories according to the structural deformation mechanism. In recent years, tectonically deformed coal and its internal structure, deformation mechanism, and chemical and physical changes (Cao et al. 2007; Ju et al. 2005, 2014a; Li et al. 2010, 2012; Song et al. $2013,2014)$ are the hot topics of coal geology. Wang et al. (2008) and $\mathrm{Ju}$ and Li (2009) reviewed the research status of tectonically deformed coal and its ultrastructure, respectively. Zhang et al. (2016) discussed the orientation growth mechanism of tectonically deformed coal microcrystals. Tectonically deformed coal research is mainly applied to structural geology and safety (Jiang et al. 2009, 2016), and the exploration and development of coalbed methane (Hou et al. 2012).

\subsubsection{Organic petrology}

At the end of the twentieth century, the development and maturity of coal petrology promoted the emergence of organic petrology. The International Coal Petrology Commission developed into The International Coal and Organic Petrology Commission. The third edition of "Coal Petrology" by Stach was published in 1982 (Stach et al. 1982) and "The Organic Petrology" was published in 1998 (Taylor 1998). Professor Kuili Jin was the first person in China to develop coal petrology into organic petrology, he proposed the classification of organic matter of continental hydrocarbon source rocks (Xiao and Jin 1990a; Wang et al. 1993a, b; Tu et al. 2012) and marine hydrocarbon source rocks (Liu 1994; Qin et al. 1996) in China. Subsequent studies were conducted on the relationship between macerals and the formation of oil and gas (Xiao and Jin 1990b). Scholars used the macerals properties of petrology and geochemistry to research organic sedimentary facies (Yao and Jin 1995; Zhang et al. 1997). Yao et al. (1997) detected a large amount of coal particles in petroleum. Above achievements were included in the monograph "Organic Petrology Research” (Jin 1997).

\subsubsection{Coalbed methane}

Different macerals and coal ranks involve different generation and storage of coalbed methane. Professor Yong Qin was the first person to apply the coal petrology method to the geology and exploration of coalbed methane in China, followed by researcher Qun Zhang (Zhang and Yang 1999). Many achievements have been made with regard to the physical and mechanical properties of coal petrology (Qin et al. 1999), as well as the coal-bodytexture and the classification of pore fissures.

\subsection{Industrial application of coal petrology}

In the past 20 years, coal petrology has been mainly applied to the physical, chemical, and technological characteristics of coal macerals in processing, conversion and utilization, guiding the effective utilization of various coals and the reduction of environmental pollution. Coal blending coking theory is relatively mature (Zhou 1985), and the development of the technical process is manifested in the difference between automation and dynamic detection of coal blending technology. With the development of technology and economy, microscopic photometers have been installed in large-to-medium-sized coking plants and coal preparation plants in China. Reflectance distribution diagrams have been widely used in coal source detection and steam coal blending. The research of maceral properties ( $\mathrm{Li}$ et al. 2007) and the separation of maceral and surface properties (Dai et al. 1998), coal-water slurry properties (Wei et al. 2003), pyrolysis characteristics (Zhang et al. 1998, 2002; Sun et al. 2002; Zhao et al. 2014a, b), gasification characteristics (Xu and Yan 2003; Tang et al. 2018a), liquefaction characteristics (Ye 2004; Xia et al. 2007; Li 2010; Wang et al. 2013), and combustion characteristics (Zheng and Wang 1992; Shu and Xu 1998; Zhang et al. 2002) have promoted the level and the pace of the industrialization of clean coal technology in China. Tang et al. (2018a) analyzed the petrological characteristics of the gasification residues and found that the dominant organic components were tenuispheres, crassispheres, tenuinetworks, crassinetworks, fusinoids, and inertoids. The micro-analysis of carrier minerals of sulfur and other hazardous elements in coal has developed into clean coal geological technology (Tang et al. 2006), which provides a scientific basis for coal desulfurization and demineralization, as well as the exploration and utilization of coal resources. 


\subsection{New coal petrologytechnologies}

The traditional methods used in coal petrology are optical microscopy and photometry, and modern coal petrology methods have been greatly improved. Firstly, by the use of light sources, such as in fluorescence and focusing confocal microscopy. Secondly, by the use of resolution, such as scanning electron microscopy (SEM) (Zhang and Li 2004), transmission electron microscopy (TEM) (Wang et al. 2017a, b, c), atomic force microscopy (AFM) (Yang et al. 1994); Wang et al. (1993b) used TEM to discover super microliptinte in vitrinite. High resolution transmission electron microscopy (HRTEM) was used to study the changes of barkinite during heating (Wang et al. 2018c). Thirdly, by the introduction of large high-technology equipment for the micro-analysis of coal macerals, such as electron microprobes, atom microprobes, proton microprobes, microscopic infrared spectra, secondary-ion mass spectrometry, and in situ plasma mass spectrometry.

In addition, nuclear magnetic resonance (NMR) method (Liu et al. 2016) was used to study liquefaction products, asphalt and macerals of coal. NMR methods can provide various structural information to judge the evolution of organic matter, maturity of crude oil, types of organic matter and sedimentary environment. Electron paramagnetic resonance (EPR) method (Qin et al. 1998a, b) needs to be combined with other methods (such as X-ray diffraction, infrared absorption spectroscopy, nuclear magnetic resonance spectroscopy) to obtain more complete information about coal structure.

The methods and equipment above have enabled scholars to break through the limitation of observing only the morphology and optical physical properties of coal macerals in the past and transformed coal petrology analysis from macro and micro-scale to molecular-scale visualization.

ICCP and TSOP are two famous international conferences on coal petrology. When the International Carboniferous Stratigraphic Conference was held in Beijing in 1987, the ICCP was first held in Beijing, China. TSOP, founded in 1983 in the United States, was held for the first time in Beijing, China, in 2006. Professor Kuili Jin of China University of Mining and Technology, Beijing won the TSOP Contribution Award in 2007. In 2012, the joint annual meeting of ICCP and TSOP was held for the first time in Beijing, marking a new height for the international status of Chinese coal and organic petrology. In August 2018, TSOP was held again in Beijing. In October 2018, Professor Kuili Jin of China University of Mining and Technology (Beijing) received the Thiessen Award of ICCP for his important achievements and outstanding contributions in the field of coal and organic petrology.

\section{Research status of Chinese coal quality}

The evaluation of coal resources potential involves not only the estimation and evaluation of reserves and resources, but also the evaluation of coal quality. Coal is endowed with heterogeneity; it is not a pure substance. There are few laws about coals and it is difficult to explain some problems (regularity) accurately by chemical reaction kinetics. Because of coal's complexity and diversity, coal sampling and sample preparation and analysis should be unified and representative.

The China Coal Standards Committee and various industry standards committees have formulated a series of standards for coal quality analysis in China. In 1958, the first coal classification in China was proposed. In the 1970s, China relaunched the project of coal classification. Chen and Yang (1985) improved the Roga index method and put forward the caking index to classify Chinese coal. The China Coal Standards Committee officially announced the new coal classification in 1986. In 2009, the China Coal Standards Committee modified the definition of coal and revised the terms and symbols of coal classification. Chen and Zhang (1995) and Chen (1999, 2000a, b, 2007), and Chen (2019) expounded in detail the principles, parameters and classification system of coal in China.

The third national coalfield prediction study produced the distribution map of Chinese coal species, which was revised by Xi' an Coal Exploration and Research Institute in 2002. In 2013, the coal quality group in the National Coal Resources Potential Evaluation published a 1:2500000 coal distribution map of China. In 2018, the National Coal Resources Potential Evaluation Project won the first prize of the Ministry of Land and Resources. Tang et al. (2013a, b) systematically analyzed the coal quality characteristics of Taiyuan Formation and Shanxi Formation in Shanxi Province, made a detailed study of the distribution of coal quality in China, and completed "The Report on Distribution of Coal Quality in China”.

The study on coal structure has always been a hot topic and the most important basic research subject of coal science. It includes two aspects (Xie 1992, 2002): one is the chemical structure of coal-that is, the molecular structure of coal; the other is the physical structure of coal-that is, the stacking structure and pore structure between molecules. Qin et al. (1998a, b) studied the physicochemical structure and solubility of low-rank coals and other organic matter and proposed a conceptual model of coal composite structure. Zeng and Xie (2004) and Zeng et al. (2005) constructed the theoretical system and methodology of Chinese coal structural chemistry and discussed coal molecular engineering and its key problems. Sun et al. (2004) carried out a quantum chemical study on the 
molecular structure model of coal macerals. Qin et al. (2008, 2010) and Qin (2017) constructed a coal composite structure model and used it to explain bonding reduction and increase of permeability, the solubility and dissolution behavior of small molecules, and the formation mechanism of caking properties. In recent years, many scholars have studied the structure of coals of different metamorphic degrees with different research methods (Li et al. 2013a, 2015, 2017; Yuan et al. 2017), the above achievements enriched the theory of coal structure.

Traditional coal quality analysis is mainly about the organic part of coal. The analysis of adverse inorganic impurities (moisture, ash, sulfur, and carrier minerals of inorganic elements) is another hot topic in coal quality research in the past 30 years. Based on the database of Chinese coal resources, the distribution characteristics of ash yield (Li and Zhai 1992), sulfur content (Chen 1994; Li and Zhai 1994; Li 1998; Luo et al. 2005) and trace elements (Bai et al. 2003) have been summarized. The analysis showed that the ash yield of Chinese commercial coal is mainly medium-low and medium (GB/T 15224.1-1994). According to the geologic era, the lowest ash yield is found in Jurassic coal and the highest ash yield in Paleogene and Neogene coal. The highest sulfur content is found in Late Permian coal in South China, followed by CarboniferousPermian coal in the Taiyuan Formation in North China, and the lowest sulfur content is found in Jurassic coal (Yuan 1999; Tang et al. 2015a, b).

Many achievements have been made in the study of sulfur in Chinese coals. The occurrence, distribution, and selectivity of sulfur in coal (Liu et al. 1985; Su 1988; Tang 1993; Lei 1993; Ren et al. 1994; Chen 1994; Li and Zhai 1994; Li 1998; Zhou et al. 1999; Luo et al. 2005; Gao et al. 2005; Hu et al. 2005a; Tang et al. 2015a, b) have been discussed in detail, and the current situation of relevant research (Zhou et al. 1999) has been clarified. There are abundant research results for organic sulfur in coal. The occurrence and distribution of organic sulfur (Tang et al. 2002; Hu et al. 2005b; Wei et al. 2015) in China has been systematically analyzed. It has been pointed out that the origin of sulfur dispersion and enrichment in coal is closely related to its sedimentary environment (Tang et al. 1996, 2015a, b; Tang et al. 2001). Origin models of organic sulfur in coal have been proposed (Lei et al. 1994; Dai et al. 2002). Shao et al. (2003) analyzed the geochemical characteristics of Heshan high-organic-sulfur coal. Dai et al. $(2008,2013)$ put forward the volcanic origin theory of high-organic-sulfur coal in Yanshan, Yunnan province, and the hydrothermal origin theory of high-organic-sulfur coal in Guangxi. The sulfur in Chenxi high-organic-sulfur coal has been studied in detail (Zhao et al. 2014a, b; Li and Tang 2014). Some scholars have discussed the geochemical regularity of trace elements with high-organic-sulfur in coal (Li et al. 2013b; Li and Tang 2013, 2014).

The primary factors affecting coal quality are generally recognized to be the coal-forming parent material (macerals transformed from plants) and coalification. Of course, the coal quality in efflorescent oxygenized belts is always worse. For coal organic matter, factors such as the Eh and $\mathrm{pH}$ values of the medium during peat formation are also causes for differences in coal quality. The other one major factor affecting coal quality is the degree of oxidation reduction (Zhao et al. 1994). Many inertinites are formed in an oxidizing environment, and vitrinite bonds formed in strong or weak reducing environments are quite different. Chen (2007) studied the reducibility of coal from a chemical point of view and put forward the concept of coal chemical faces. For the inorganic composition of coal, the mineral matter (ash yield) and sulfur content, as well as the major and trace elements, are undoubtedly related to the coal-accumulating environment. Modern coal quality research has been closely integrated with the system tracts of the sedimentary environment and sequence stratigraphy, which enriched the coal-forming theory and provided a scientific basis for the potential of clean coal processing and utilization.

In China, according to the classification of coal quality and the utilization of coal, new varieties of coal and new concepts have been produced.

(1) High-quality coal. The quality of coal is classified according to classification indicators. The National Technical Committee for Coal Standardization graded the ash yield, sulfur content, and calorific value of coal in 1994, 2004, and 2010, respectively, and ash yield grading was revised in 2018 (GB/T 15224.1-2018). Luo et al. $(2015,2019)$ interpreted and discussed the national standards for civil and commercial coal. Ash yield and sulfur content of coal resources were ranked statistically in the third coalfield prediction study (Mao and Xu 1996). The concept of high-quality coal was put forward according to its ash yield, sulfur content, calorific value, and washability (Yuan 1999). Cao and Zhao (2003) also put forward three suggestions on attaching importance to the research on high-quality coal resources. When $\mathrm{Li}$ et al. (2005) developed the western coal resources, the concept of high-quality coal was redetermined and classified; then, she categorized high-quality coal in the Ordos Basin ( $\mathrm{Li}$ 2008). Qin et al. (2006) also proposed the classification and overall composition of Chinese highquality environmental-friendly steam coal types. 
(2) Clean coal geology. In view of the impurities and hazardous elements in coal, CNACG appointed experts and scholars to carry out a study of clean coal geology. Various hazardous elements were classified and the clean potential of gas, liquid, and solid utilization was classified into four or five grades (Tang et al. 2006). Wang et al. (2005a) studied the potential pollution comprehensive index and the clean class of hazardous elements in coal. Yang et al. (2011) put forward a classification into six grades and extended it to the evaluation of potential coal resources in various provinces and cities (Chongqing, Guizhou, Hunan, Anhui, and Shanxi). Tang et al. (2012, 2013a, b) classified grade six of coal quality according to the geological characteristics of coal and applied it to the evaluation of coal resources in Shanxi and Inner Mongolia. Based on the clean and efficient utilization of coal, Xie (2014a, b) compiled the "Coal Clean Efficient Conversion" and "China Coal Clean, Efficient, Sustainable Development and Utilization Strategy Research". The National Energy Administration issued the "Coal Clean and Efficient Utilization Action Plan (2015-2020) “ in April 2015, which set a clear timetable for the clean and efficient utilization of coal in the next 5 years. In October 2018, the International Pittsburgh Coal Conference (PCC) was held in Xuzhou. Scholars exchanged ideas on the theme of "clean coal-based energy, fuel and environment".

(3) Special and scarce coal. With the production and consumption of coal in China, gas coal, fat coal, coking coal, lean coal, and meager coal for coking have been scarce. The scarcity of high-quality blast furnace injection coal and activated carbon coal, coal rich in beneficial elements (such as germanium, gallium, and lithium), and the environmental hazards of high sulfur, high arsenic, and high mercury in coal, led to the emergence of "special and scarce coal". Dai and Cheng (1991), Han (1996), and Zeng (2001) put forward the concept of special coal. Dai (2006b, 2010, 2012b, 2015a, b, 2018) and Qin (2009) studied the germanium and gallium resources in coal. Wang and Cao (1990), Ma (2004), and Guo (2018) analyzed coal for coking, blast furnace injection, activated carbon, carbon products, gasification, and other industrial raw materials. Suggestions on strengthening macro-control and rationally organizing production were put forward. The "Classification and Utilization of Scarce and Special Coal Resources" (GB/T 26128-2010) was put forward by the "Standardization Administration of China". In 2010, CNACG undertook the project "Survey of
Scarce and Special Coal Resources", organized by the Ministry of Land and Resources. In January 2013, Professor Shifeng Daiput forward the concept of "coal-hosted rare-metal minerals" in Hangzhou. Then, he used coal-hosted germanium, gallium, uranium, niobium, rare-earth elements, and other rare-metal deposits as examples to discuss the geological origins, occurrence, and utilization evaluation methods of these deposits (Dai et al. 2014, 2018). Sun et al. (2014) proposed the minimum mining standards for lithium, uranium, thorium, and rare earths in coal. The experts and scholars participating in the 35th International Conference on Organic Petrology (TSOP) in 2018 conducted field research of the Wulantuga coalhosted germanium deposit in Inner Mongolia.

\section{Research status of coalification and coal metamorphism}

Coalfield Professional Commission of China Geological Society (2003) summarized the characteristics of Chinese coal metamorphism research before 1997: the hydrothermal metamorphism type of coal and the new hydrothermal metamorphism of coal were proposed and determined in the 1980s and 1990s. Academician QiYang (1996a, b) put forward the theory of multi-stage evolution and heat-source superposition metamorphism of coal in China and pointed out that there are four types of heat sources: geothermal, magma, hydrothermal, and the high temperature of deep faults. Coal metamorphism can be divided into two categories: deep metamorphism and abnormal thermal superimposed metamorphism; the latter can be further divided into five types. Professor Dexin Han (1996) divided the metamorphic types into six types: deep metamorphism, magmatic thermo-metamorphism metamorphism, magmatic contact metamorphism, hydrothermal metamorphism, tectonic dynamic metamorphism, and burnt metamorphism. Yang Q (1996a, b), Li (1997), and Wu (1995) put forward the coal metamorphic zoning (belt) and distribution in China.

In the past 25 years, the new achievements in the study of coalification and coal metamorphism in China are mainly as follows, these results enriched the theory of coal metamorphism:

(1) Based on the evolution process of the molecular structure of coal, Qin et al. (1998a, b) put forward the superposition and electron paramagnetic resonance (EPR) step evolution for high-rank coals. Ju et al. (2005) studied the relationship between the nanoscale deformation and the metamorphic 
deformation environment of the coal structure. The relationship between geological processes and coal quality (Fu et al. 2016) have been discussed.

(2) The catalytic effects of tectonic deformation on coalification from the stress degradation mechanism and the stress polycondensation mechanism have been explored (Cao et al. 2007); the relationship between coal structure and stress has been explained (Qu et al. 2012, 2015; Ju et al. 2014a), and new parameters of the coal deformation degree index have been put forward (Wei et al. 2017).

(3) The principles and methods of thermodynamic analysis have been combined with the evolutionary history of crust, the history of the thermal evolution of coal basins, and the geochemical characteristics of coal to study coal metamorphism as a dynamic process (Wu et al. 1997; Ren et al. 2007). Based on geothermal fields, the change of coal metamorphism under the synergistic action of geothermal anomaly and magmatic rocks has been analyzed (Wang et al. 2017a, b, c)

(4) In practice, scholars have used logging curves to identify coal rank (Mao et al. 2011b). XRD hasbeen used to analyze coal metamorphic regularity (Zhang et al. 2010). The geological exploration and development of oil and gas and the utilization of coalbed methane have become hot research areas.

\section{Research status of geochemistry of coal}

In the past 20 years, China has attached great importance to the research of coalbed methane and clean coal technology and has invested a large amount of funding in 973 basic research plans and 863 technology projects, as well as a national support plan and major special projects. Up to now, three Ph.D. thesis examining the trace elements of coal, one Ph.D. thesis studying coal-derived oils, and two Ph.D. thesis investigating coalbed methane have won the title of 100 Excellent Doctoral Dissertations in China. Therefore, both inorganic and organic geochemistry are hot areas of coal quality research.

\subsection{Inorganic geochemistry of coal}

The study on trace elements in coal has always been an important subject in coal quality. In the 1980s, Sun and Jervis (1986) and Chen et al. (1985, 1989a, b) reported data of trace elements in the first batch of more than 100 coal samples and analyzed the distribution trend of trace elements in Chinese coals, which marked that coal geochemistry in China entered a systematic research stage.
Ren et al. (1999, 2006) discussed the distribution characteristics and origins of trace elements in Chinese coals. Bai et al. (2003) analyzed the average contents of trace elements in Chinese coals based on the resources database. Tang and Huang (2004) conducted a detailed research on the trace elements in Chinese coal and clarified the significance of this study; their research results are published in "Trace Elements in Coal", which contains the background values of 44 trace elements in Chinese coals from different regions. Ren et al. (2006) systematically reviewed the occurrence characteristics and distribution of trace elements in coalfield exploration and coal mines in China; these results are published in "Geochemistry of Trace Elements in Coal". The latest summary study on the distribution of trace elements in Chinese coal was carried out by Dai et al. (2012a) and examined the content, enrichment, and occurrence of trace elements in China.

Dai et al. (2005) systematically summarized the occurrence and distribution characteristics of major elements in Chinese coal, introduced the concept of "reserve weight" (Ren et al. 2006), and put forward the background values of elements in Chinese coal.

Research has been conducted on some elements in coal: mercury (Zhou 1994; Feng et al. 2001; Bai et al. 2017), fluorine (Luo et al. 2004; Wu et al. 2005), arsenic (Zhao et al. 1998; Chen and Tang 2002), selenium (Zheng 1991; Zhu et al. 2003), uranium (Yao 1988; Chen et al. 2018), lithium (Sun et al. 2013), gallium (Dai et al. 2006b, 2018; Qin et al. 2009), germanium (Hu et al. 1996, 1997; Du et al. 2003; Dai et al. 2012b, 2015a, b), platinum (Dai et al. 2003), and rare earth elements (Zhao 2002; Dai et al. 2018). Many scholars have used the trace elements in coal as the main research object to complete their dissertations, such as Fenghua Zhao, Junying Zhang, Shifeng Dai, Guijian Liu, Liugen Zheng, Cuicui Qi, Jianming Zhu, Daizhen Wu, Mingshi Wang, Wenfeng Wang, Yuhong Xia, Wei Wang.

Extensive research on the migration and distribution of elements in coal in washing (Wang et al. 2005b; Duan 2017), liquefaction (Xia 2009), combustion (Wang et al. 2003; Zhang et al. 2003, 2007), and gasification (Tang et al. 2018a; Wang et al. 2018a, b, c, d, 2019) has also been carried out. Ren and Dai (2009) proposed that we should pay close attention to associated and accompanying mineral resources in coal and coal-bearing strata. Dai et al. (2010, 2012a, 2014, 2016, 2018) pointed out the presence of $\mathrm{Nb}$ and other rare-metal deposits in Permian coal-bearing strata in Southwestern China.

Studies on healthy effects of elements in coal have always been a hot topic. Zheng et al. (1999) reviewed the health and disease problems caused by As and F in coal in Southwest China. In 2002, the International Medical Geology Lecture was introduced at China University of 
Mining and Technology (Beijing). Tang (2005) reviewed the research status of medical geology and established an elective course for graduate students, "Medical Geology". Baoshan Zheng translated the monograph "Medical Geology" (Selinus et al. 2005). Dai et al. (2004) pointed out that the cause of fluorosis was abnormally high fluorine content in clay, which was used as an additive for coal burning. The International Conference on Medical Geology was held in Guiyang, Guizhou Province in August 2019.

\subsection{Organic geochemistry of coal}

Organic geochemistry of coal is a science that studies on the composition, structure, and hydrocarbon evolution of coal organic matter. The study of biomarkers is the basis of organic geochemistry of coal, and carbon and hydrogen isotopes are its main research means. Recent advances are mainly in the study of coal-formed hydrocarbons-that is, the study of coal-formed oil and coal-formed gas.

Some achievements have been made in coal geochemistry regarding coal-based products and non-fuel utilization of coal. In 1999, fullerenes (C60) were found in Yunnan coal and began to be studied. Since the advent of graphene in 2004, many scholars have studied coal-based graphene and coal-based graphene quantum dots (Zhang 2015; Tang et al. 2018b; Huan et al. 2019; Huan 2019) according to the characteristics of coal petrology.

Regarding coal-formed oil, there are some monographs written by Fu (1990), Huang (1992, 1995), Fu and Qin (1995), and Wang (1998), and so on. These monographs were popular in China in the 1980s and 1990s and systematically examined the achievements of organic geochemistry of coal in China. "Hydrocarbon Source Rocks in China", written by Qin (2005), elaborates on hydrocarbon generation and migration of hydrocarbon source rocks types in a coal-forming environment. Advances in the research of coal-formed oil include: signs of coal-formed oil (Hu 1998); mechanisms of coal-formed hydrocarbon generation; hydrocarbon expulsion from coal-bearing strata; evaluation of hydrocarbon generation potential of coal hydrocarbon source rocks; distribution of coal-formed oil (Huang and $\mathrm{Lu} \mathrm{1999).}$

Academician Dai (1982) determined the definition of coal-formed gas in 1982. Chen et al. (1999) considered that the coal-bearing mudstone in the Northwest region, especially in the Turpan-Hami Basin, was the main hydrocarbon source rock, and coal and carbonaceous mudstone were the secondary hydrocarbon source rocks. Su (2005) considered that crude oil from the Middle Jurassic in Northern Sag of Turpan-Hami Basinis strictly not "coalformed oil", but "source-mixed oil" formed by deep lacustrine facies and coal-bearing hydrocarbon source rocks. Chen et al. (2006) believed that vitrinite and collodetrinite have a relatively low potential of hydrocarbon generation and do not easily become the main macerals for coal-formed oil, but they can be good gas-prone macerals at the stage of high maturity to over-maturity. Fusinite has an extremely low potential of hydrocarbon generation and cannot be the organic matter for oil generation.

Coalbed methane is an unconventional natural gas formed and reserved in coal seams. Coalbed methane research involves many subjects, such as coalfield geology, natural gas geology, geochemistry, physics, chemistry, seepage mechanics, and so on. It is generally believed that liptinite and vitrinite are the macerals with the strongest potential of gas generation and that inertinite is the weakest. The types of coalbed methane are mainly determined by carbon and hydrogen isotopes (Tao 2005), the origins of coalbed methane are diverse (Qin 2012; Ju et al. 2014b), and the distribution, occurrence, and enrichment patterns of coalbed methane are significantly affected by geological factors (Qin et al. 2017; Liu and Li 2014).

It is generally recognized that coalbed methane is an autogenic and self-reserved unconventional natural gas. The gas content at a certain point in a gas reservoir is the instantaneous value at the dynamic equilibrium state of desorption-absorption-diffusion-seepage (migration), which varies with changes in reservoir temperature, pressure, concentration difference, pressure difference, and water flow. A coalbed methane reservoir has the characteristics of dual-porosity and dual-permeability and has internal and external fractures, face cleats and butt cleats, and pore types (Zhang 2001; Fu et al. 2005). The porefracture heterogeneity of coalbed methane reservoirs is controlled by four main geological factors (Liu et al. 2015). Permeability has been classified (Su and Fang 1998; Kang et al. 2017), coal reservoir permeability varies with different gas production stages (Tang et al. 2015a, b), and coalbed methane reservoir permeability is affected by five main factors (Wang et al. 2017a, b, c).

\section{Prospects}

The characteristics of Chinese resource determine that China is still a big country with coal as the main energy consumption structure. There are still many coal science and engineering problems under exploration, exploitation, processing, conversion, and utilization. China should be the world research center of coal. Resource-saving and clean coal utilization are not only requirements of the world, but also the desire of the nation and the people.

(1) Traditional coal petrology is based on optical microscopy. Modern coal petrology breaks through the limitation of low resolution of optical 
microscopy and moves towards electron microscopy and micro-analysis. Using advanced science and technology from both petrology and geochemistry and in the macroscopic, naked-eye, microscale, molecular, and atomic level, the composition and evolution of coal are studied and the research field is expanded.

(2) Recently, researchers at Massachusetts Institute of Technology (MIT) developed a central process unit (CPU) by carbon nanotube (CNT), which some believe is the beginning of artificial carbon-based life. Coal is the most ideal carbon source, which can provide strong material support for carbon-based revolution and artificial carbon-based life. We believe that under the support of coal petrology theory, great progress will be achieved in coal-based carbon materials and high-tech carbon products in the future. Nowadays, the progress of bioscience will promote the theoretical study of coal organic matter, improve the utilization rate of its useful components, detect the effective removal and recycling of coal inorganic matter, and provide a scientific basis and technical assurances for clean coal technology and environmental protection.

(3) Coal is the product of long-term geological evolution, there are a lot of ancient information about geology, geography, climate and biology in coal. The study on coal petrology will be helpful to the exploration of the origin of the universe and human beings in the future. A great deal of ancient information and advanced knowledge cracked in the process of coal petrology research will also contribute to the study of relevant modern basic theories. The research of deep space science, deep drilling science, and deep sea science, the intersection and integration of multiple disciplines, the introduction of new theories, and the wide application of advanced technologies — such as cloud computing, big data and artificial intelligence-will bring new research and applications of new energy sources and materials based on coal petrology and organic petrology.

(4) The research on coal petrology will improve the scientificity and safety of coal mining in China, and promote the efficient processing and utilization of coal chemical industry. The unique coal chemical products (such as graphene and hydrogen energy) and rare metals in coal are important sources of future medical and military materials. In addition, the study of coal petrology will also promote the development of optical, thermal, mechanical and electrical instruments in the future.
In the future, new achievements will emerge in the fields of coal geochemistry, clean coal utilization, coal-based materials (coal-based carbon materials, fullerene, coal-associated minerals), coalbed methane, shale gas, and in basic research and the technological development of new fossil fuel energy.

Acknowledgements This research was supported by the National Natural Science Foundation of China (41572146, 41872175), National Basic Research Program of China (2014CB238905, 2012CB214901), the National Coal Resource Potential Evaluation Project (1212011121043), the National Special, Scarce Coal Resource Survey Project (121201002020) and the National Natural Science Foundation of China (No. 41872175).

Open Access This article is licensed under a Creative Commons Attribution 4.0 International License, which permits use, sharing, adaptation, distribution and reproduction in any medium or format, as long as you give appropriate credit to the original author(s) and the source, provide a link to the Creative Commons licence, and indicate if changes were made. The images or other third party material in this article are included in the article's Creative Commons licence, unless indicated otherwise in a credit line to the material. If material is not included in the article's Creative Commons licence and your intended use is not permitted by statutory regulation or exceeds the permitted use, you will need to obtain permission directly from the copyright holder. To view a copy of this licence, visit http://creativecommons. org/licenses/by/4.0/.

\section{References}

Bai XF, Ding H (2016) Modern coal quality technology. China Petrochemical Press, Beijing

Bai XF, Li WH, Chen YF, Jiang Y (2003) The general distributions of trace elements in Chinese coals. Coal Qual Technol 1:1-4

Bai XF, Li WH, Wang Y, Ding H (2017) The distribution and occurrence of mercury in Chinese coals. Int J Coal Sci Technol 4(2):172-182

Cao DY, Zhao FH (2003) Attach importance to study of high-quality coal resource characteristics. China Min Mag 12(10):21-23

Cao DY, Li XM, Zhang SR (2007) Influence of tectonic stress on coalification-stress degradation mechanism and stress polycondensation mechanism. Sci China Seri D Earth Sci 2007(1):45-56

Chen P (1994) Characteristics and distribution of sulfur in Chinese coals and desulfurization. Coal Convers 2:1-9

Chen PY (1996) Coal petrologic atlas of China. China Coal Industry Publishing House, Beijing

Chen P (1999) Study on classification of coal seam in China. Coal Sci Technol 27(1):39-42

Chen P (2000a) Coal classification in China: a complete system (Part I). China Coal 26(9):5-8 (in Chinese with English abstract)

Chen P (2000b) Coal classification in China: a complete system (Part II). China Coal 26(10):7-11 (in Chinese with English abstract)

Chen P (2007) Nature, classification and utilization of China coal, 2nd edn. Chemical Industry Press, Beijing (in Chinese)

Chen YF (2019) Handbook of general classification standards for coal. China Coal Industry Publishing House, Beijing (in Chinese)

Chen P, Ma JS (2002) Petrographic characteristics of Chinese coals and their application in coal utilization processes. Fuel 81(11):1389-1395 
Chen P, Tang XY (2002) Arsenic in coal of China. Coal Geol China 14(s1):18-24

Chen P, Yang JH (1985) New index for bituminous coal classification-caking index. Coal Sci Technol 11:9-12

Chen P, Zhang YF (1995) Subbituminous coal and its classification in China. J China Coal Soc 6:572-577

Chen BR, Qian QF, Yang YN, Yang SJ (1985) Concentration distribution of trace elements in 107 coal mines in China. Chin Sci Bull 30(1):27-29

Chen BR, Yang SJ, Qian QF, Yang YN (1989a) Content distribution of arsenic, selenium, chromium, uranium and thorium in coal mines of China. Environ Sci 6:23-68

Chen SQ, Chen JH, Zhao SJ (1989b) Petrographic characteristics of coal and coal facies analysis of the upper member of the Late Permian coal formation in Tianba and Tuchen. Acta Sedimentol Sin 2:79-87

Chen JP, Zhu XS, Guo SJ, Wang G, He X (1999) The discovery and its significance of oil sands in Jurassic formation in Northwest. Acta Pet Sin 3:13-18

Chen JP, Deng CP, Wang HT, Han DX (2006) Genetic potential and geochemical features of pyrolysis oils of macerals from Jurassic coal measures, Northwest China. Geochimica 35(1):81-87

Chen J, Chen P, Yao DX, Huang WH (2018) Geochemistry of uranium in Chinese coals and the emission inventory of coalfired power plants in China. Int Geol Rev 60(5-6):621-637

China National Administration of Coal Geology (2016) China occurrence regularity of coal resources and resource evaluation. Science Press, Beijing

Coalfield Professional Commission of China Geological Society, China Coal Society (2003) China coalfield geology in development. Coal Geol Exp 31(6):1-5

Dai JX (1982) The definition and classification of coal-formed gas. Geol Rev 4:370-372

Dai HW, Cheng YJ (1991) Research into Tianzhu coal and Tianzhu coal application. Coal Sci Technol 5:38-43

Dai SF, Ren DY, Peng SP, Mao HL, Zhou Q, Zhang JH, Li BC (1998) The study on the relationship between the petrology microcharacteristics and depositional environment of coal in Wuda coal field in Inner Mongolia. Acta Sedimentol Sin 3:141-146

Dai SF, Ren DY, Tang YG, Shao LY, Li SS (2002) Distribution, isotopic variation and origin of sulfur in coals in the Wuda coalfield, Inner Mongolia, China. Int J Coal Geol 51(4):237-250

Dai SF, Ren DY, Zhang JY, Hou XQ (2003) Concentrations and origins of platinum group elements in Late Paleozoic coals of China. Int J Coal Geol 55(1):59-70

Dai SF, Ren DY, Ma SM (2004) The cause of endemic fluorosis in western Guizhou Province, Southwest China. Fuel 83(14-15):2095-2098

Dai SF, Ren DY, Tang YG (2005) Modes of occurrence of major elements in coal and their study significance. Coal Geol Exp 2:1-5

Dai SF, Han DX, Chou CL (2006a) Petrography and geochemistry of the middle devonian coal from Luquan, Yunnan Province, China. Fuel 85(4):456-464

Dai SF, Ren DY, Li SS (2006b) Discovery of the superlarge gallium ore deposit in Jungar, Inner Mongolia, North China. Chin Sci Bull 51(18):2243-2252

Dai SF, Ren DY, Li SS, Zhao L, Zhang Y (2007) Coal facies evolution of the main minable coal-bed in the Heidaigou Mine, Jungar Coalfield, Inner Mongolia, northern China. Sci China 50(S2):144-152

Dai SF, Ren DY, Zhou YP, Chou CL, Wang XB, Zhao L, Zhu XW (2008) Mineralogy and geochemistry of a superhigh-organicsulfur coal, Yanshan coalfield, Yunnan, China: evidence for a volcanic ash component and influence by submarine exhalation. Chem Geol 255(1):182-194
Dai SF, Zhou YP, Zhang MQ, Wang XB, Wang JM, Song XL, Jiang YF, Luo YB, Song ZT, Yang Z, Ren DY (2010) A new type of $\mathrm{Nb}(\mathrm{Ta})-\mathrm{Zr}(\mathrm{Hf})-\mathrm{REE}-\mathrm{Ga}$ polymetallic deposit in the late Permian coal-bearing strata, eastern Yunnan, southwestern China: possible economic significance and genetic implications. Int $\mathrm{J}$ Coal Geol 83(1):55-63

Dai SF, Ren DY, Chou CL, Finkelman RB, Seredin VV, Zhou YP (2012a) Geochemistry of trace elements in Chinese coals: a review of abundances, genetic types, impacts on human health, and industrial utilization. Int J Coal Geol 94(3):3-21

Dai SF, Wang XB, Seredin VV, Hower JC, Keefe JMK, Ward CR, Huang WH, Li T, Li X, Liu DH, Xue WF, Zhao LX (2012b) Petrology, mineralogy, and geochemistry of the Ge-rich coal from the Wulantuga Ge ore deposit, Inner Mongolia, China: new data and genetic implications. Int J Coal Geol 90:9172-9199

Dai SF, Zhang WG, Seredin VV, Word CR, Hower JC, Song WJ, Wang XB, Li X, Zhao LX, Kang H, Zheng LC, Wang PP, Zhou D (2013) Factors controlling geochemical and mineralogical compositions of coals preserved within marine carbonate successions: a case study from the Heshan Coalfield, southern China. Int J Coal Geol 109-110:77-100

Dai SF, Ren DY, Zhou YP, Seredin VV, Li DH, Zhang MQ, Hower JC, Ward CR, Wang XB, Zhao L, Song XL (2014) Coal-hosted rare metal deposits: genetic types, modes of occurrence, and utilization evaluation. J China Coal Soc 39(8):1707-1715

Dai SF, Wang PP, Ward CR, Tang YG, Song XL, Jiang JH, Hower JC, Li T, Seredin VV, Wagner NJ, Jiang YF, Wang XB, Liu JJ (2015a) Elemental and mineralogical anomalies in the coalhosted Ge ore deposit of Lincang, Yunnan, southwestern China: key role of $\mathrm{N}_{2}-\mathrm{CO}_{2}-$ mixed hydrothermal solutions. Int $\mathrm{J}$ Coal Geol 152:19-46

Dai SF, Liu JJ, Ward CR, Hower JC, Xie PP, Jiang YF, Hood MM, O'Keefe JMK, Song HJ (2015b) Petrological, geochemical, and mineralogical compositions of the low-Ge coals from the Shengli Coalfield, China: a comparative study with Ge-rich coals and a formation model for coal-hosted Ge ore deposit. Ore Geol Rev 71:318-349

Dai SF, Liu JJ, Ward CR, Hower JC, Seredin VV, French D, Jia SH, Hood MM, Garrison TM (2016) Mineralogical and geochemical compositions of Late Permian coals and host rocks from the Guxu Coalfield, Sichuan Province, China, with emphasis on enrichment of rare metals. Int J Coal Geol 166:71-95

Dai SF, Hower JC, Ward CR, French D (2018) Enrichment of Bi-Be$\mathrm{Mo}-\mathrm{Cd}-\mathrm{Pb}-\mathrm{Nb}-\mathrm{Ga}$, REEs and $\mathrm{Y}$ in the Permian coals of the Huainan Coalfield, Anhui China: discussion. Ore Geol Rev 102:940-948

Du G, Tang DZ, Wu W, Sun PC, Bai YL, Xuan YQ, Huang J (2003) Preliminary discussion on genetic geochemistry of paragenetic germanium deposit in Shengli coalfield, Inner Mongolia. Geoscience 17(4):453-458

Duan PP (2017) Geochemistry of toxic elements in high-sulfur coal from Southwest China and their partitioning during coal preparation. Ph.D thesis, China University of Mining and Technology

Feng XB, Hong YT, Hong B, Ni JY, Zhu YX (2001) Modes of occurrence of mercury in coal. Bull Miner Pet Geochem 20(2):71-78

Fu JM (1990) Geochemistry of coal-formed hydrocarbon. Science Press, Beijing

Fu JM, Qin KZ (1995) Kerogen geochemistry. Guangdong Science and Technology Press, Guangzhou

Fu XH, Qin Y, Zhang WH, Wei CT, Zhou RF (2005) Fractal classification and natural classification of coal porestructure based on migration of coal bed methane. Chin Sci Bull 50(S1):66-71 
Fu B, Liu GJ, Liu Y (2016) Coal quality characterization and its relationship with geological process of the early Permian Huainan coal deposits, southern North China. J Geochem Exp 166:33-44

Gao JF, Liu GJ, Chou CL, Zheng LG, Zheng W (2005) The study of sulfur geochemistry in Chinese coals. Bull Miner Pet Geochem 1:79-87

GB/T 15224.1-2018 (2018) Classification for quality of coal-Part 1: Ash. Standardization Administration of China

GB/T 15224.1-1994 (1994) Classification for quality of coal-classification for ash yield of coal. Standardization Administration of China

GB/T 15588-2013 (2013) Classification of macerals for bituminous coal. Standardization Administration of China

GB/T 15588-2001 (2001) Classification of macerals for bituminous coal. Standardization Administration of China

GB/T 15588-1995 (1995) Classification of macerals for bituminous coal. Standardization Administration of China

GB/T 30050-2013 (2013) Classification of coal-body structure standardization. Administration of China

GB/T 26128-2010 (2010) Classification and utilization of scarce and special coal resources. Standardization Administration of China

Guo JC (2018) Progress in the preparation and development trend of coal-based activated carbon. China Pet Chem Stand Qual 38(22):102-103

Guo YT, Renton JJ, Penn JH (1996) FTIR microspectroscopy of particular liptinite-(lopinite)—rich, late permian coals from Southern China. Int J Coal Geol 29(1-3):187-197

Han DX (1980) China coalfield geology. Coal Industry Publishing House, Beijing

Han DX (1996) Coal petrology of China. China University of Mining \& Technology Press, Xuzhou

Han DX, Ren DY, Guo MT (1983) Origin of bark liptobiolite and its depositional environment of Changguang coal field, Zhejiang Province. Acta Sedimentol Sin 4:4-17

Hou QL, Li HJ, Fan JJ, Ju YW, Wang TK, Li XS, Wu YD (2012) Structure and coalbed methane occurrence in tectonically deformed coals. Science China (Earth Sci) 55(11):1755-1763

Hower JC, Robertson JD, Elswick ER, Roberts JM, Brandsteder K, Trimble AS, Mardon SM (2007) Further investigation of the impact of the co-combustion of tire-derived fuel and petroleum coke on the petrology and chemistry of coal combustion products. Energy Sources Part A Recov Util Environ Effects 29(5):439-461

Hsleh CY (1933) On lopinite, a new type of coal in China. Acta Geol Sin English Ed 12(1-2):469-490

$\mathrm{Hu}$ SR (1998) The theories and practices of coal-formed oil. Seismological Press, Beijing

Hu RZ, Bi XW, Ye ZJ, Su WC, Qi L (1996) The genesis of Lincang germanium deposit-a preliminary investigation. Acta Miner Sin 2:97-102

Hu RZ, Bi XW, Su WC, Ye ZJ (1997) Some considerations on germanium mineralization in coal-as exemplified by Lincang germanium deposit. Acta Miner Sin 4:364-368

Hu J, Zheng BS, Wang MS, Finkleman RB (2005a) Distribution and forming cause of sulfur in chinese coals. Coal Convers 28(4):1-6

Hu J, Zheng BS, Wang BB, Finkleman RB (2005b) Distribution and forming cause of organic sulfur in coals of China. Coal Geol Exp 33(5):12-15

Hu SR, Peng JC, Hao GQ, Wang HS, Zhao JB, Chen DY (2012) Geotectonic theory and the fourth prediction for potential evaluation of China's coalfields. Coal Geol Exp 40(3):1-5

Huan X (2019) Study on the influencing factors of coal-based graphene and coal-based graphene quantum dots structure. Ph.D thesis, China University of Mining and Technology (Beijing)
Huan X, Tang YG, Xu JJ, Lan CY, Wang SQ (2019) Structural characterization of graphenic material prepared from anthracites of different characteristics: a comparative analysis. Fuel Process Technol 183:8-18

Huang DF (1992) Advances in geochemistry of oil derived from coals. Petroleum Industry Press, Beijing

Huang DF (1995) Oil from coal: formation and mechanism. Petroleum Industry Press, Beijing

Huang DF, Lu SF (1999) Current situation and prospect in geochemistry of oil from coals. Earth Sci Front (China University of Geosciences, Beijing) 6(b05):183-194

Jiang B, Qin Y, Ju YW, Wang JL, Li M (2009) The coupling mechanism of the evolution of chemical structure with the characteristics of gas of tectonic coals. Earth Sci Front (China University of Geosciences, Beijing; Peking University) 2:262-271

Jiang B, Li M, Qu ZH, Liu JG, Li W (2016) Current research status and prospect of tectonically deformed coal. Adv Earth Sci 31(4):335-346

Jiao K, Yao SP, Zhang K (2012) An atomic force microscopy study on "barkinite" liptobiolith. Geol Rev 58(4):775-782

Jin KL (1997) Research on organic petrology - a case study of the Tarim. Seismological Press, Beijing

Jin KL, Qin Y (1989) Coal petrology and anomalous coalification of Middle and Late Pleistocene peat and soft brown coal from the Tengchong Basin, Western Yunnan, People's Republic of China. Int J Coal Geol 13(1-4):143-170

Ju YW, Li XS (2009) New progress in the study of ultrastructure of tectonically deformed coal. Progress Nat Sci 19(02):131-140

Ju YW, Jiang B, Hou QL (2004) The new structure-genetic classification system in tectonically deformed coals and its geological significance. J China Coal Soc 29(5):513-517

Ju YW, Jiang B, Hou QL, Wang GL (2005) Relationship between nanoscale deformation of coal structure and metamorphicdeformed environments. Chin Sci Bull 50(16):1785-1796

Ju YW, Kray L, Li XS, Wang GC, Yan ZF, Wei MM, Yu LY (2014a) Micro-structural evolution and their effects on physical properties in different types of tectonically deformed coals. Int J Coal Sci Technol 1(3):364-375

Ju YW, Li QG, Yan FZ, Sun Y, Bao Y (2014b) Origin types of CBM and their geochemical research progress. J China Coal Soc 39(5):806-815

Kang YS, Sun LZ, Zhang B, Gu JY, Mao DL (2017) Discussion on classification of coalbed reservoir permeability in China. J China Coal Soc 42(S1):186-194

Lei JJ (1993) Occurrence of sulfur in coals from the Late Permian in Guizhou-Also on the structure, composition and genesis of high organic sulfur coal. Ph.D thesis, China University of Mining and Technology (Beijing)

Lei JJ, Ren DY, Tang YG, Chu XL, Zhao R (1994) Sulfuraccumulating model of superhigh organosulfur coal from Guiding, China. Chin Sci Bull 39(21):1817-1821

Li HM (1997) Coal petrology and quality characteristics and metamorphic rules of Chinese coal. Geological Publishing House, Beijing

Li R (1998) Distribution of sulfur in Chinese coal. Clean Coal Technol 4(1):44-47

Li XY (2008) Classification and evaluate of the Jurassic Premium coal resources in Shaanxi-Gansu-Ningxia Basin, China. Geological Publishing House, Beijing

Li XY (2010) Discussion on liquefaction reactivity of lithotype and maceral of low rank coal. Coal Geol Exp 38(3):1-5

Li WW, Tang YG (2013) Characteristics of the rare earth elements in a high organic sulfur coal from Chenxi, Hunan province. J Fuel Chem Technol 41(5):540-549 
Li WW, Tang YG (2014) Sulfur isotopic composition of superhighorganic-sulfur coals from the Chenxi coalfield, southern China. Int J Coal Geol 127:3-13

Li WH, Zhai J (1992) Distribution of ash yield in coal in China. Coal Process Compr Util 4:7-10

Li WH, Zhai J (1994) The distribution of sulfur in Chinese coal and the means controlling sulfur pollution. Coal Convers 4:1-10

Li WH, Chen YF, Chen WM, Li XL (2000) Distribution features of micro-constituents for coal in China main mining area. Coal Sci Technol 9:31-34

Li XY, Jin XL, Li GH (2005) The definition of fine coal and the consideration for its utilization problem in exploitation of coal resource in Western China. Coal Geol China 3:5-8

Li JL, Wu GG, Meng XL, Gu TY, Kang H (2007) Coal petrology microscopic properties: research progress. China Coal 33(12):62-64

Li XS, Ju YW, Hou QL, Li H (2010) Influence mechanism of tectonic deformation on macromolecular chemical structure of coals: a case study of vitrinite separation of tectonically deformed coals. J China Coal Soc 35(S1):150-157

Li XS, Ju YW, Li XS, Ju YW, Hou QL, Li H (2012) Spectra response from macromolecular structure evolution of tectonically deformed coal of different deformation mechanisms. Sci China (Earth Sci) 55(8):1269-1279

Li MF, Zeng FG, Chang HZ (2013a) Aggregate structure evolution of low-rank coals during pyrolysis by in situ X-ray diffraction. Int J Coal Geol 116(5):262-269

Li WW, Tang YG, Deng XJ, Yu XL (2013b) Geochemistry of the trace elements in the high-organic-sulfur coals from Chenxi coal field. J China Coal Soc 38(7):1223-1227

Li X, Zeng FG, Wang W (2015) FTIR characterization of structural evolution in low-middle rank coals. J China Coal Soc 40(12):2900-2908

Li MF, Zeng FG, Zhao YG, Liang HZ, Xiang JH (2017) Structural evolution around first coalification jump revealed by TG/MS and FTIR. Energy Sources Part A Recov Util Environ Effects 39(6):562-569

Liu DM (1994) A review on studies of organic petrology. Adv Earth Sci 9:18-23

Liu DM, Li QJ (2014) Main geological controls on distribution andoccurence and enrichment patterns of coalbed methane in China. Coal Sci Technol 42(6):19-24

Liu YJ, Chen P, Yuan JY, Tong XA, Chen WM (1985) Study on distribution of sulfur content Chinese coals-based on information. Coal Sci Technol 7:8-12

Liu DM, Li ZT, Cai YD (2015) Study progress on pore-crack heterogeneity and geological influence factors of coal reservoir. Coal Sci Technol 43(2):10-15

Liu YL, TangDZ X, Zhao JL, Li BY (2016) Description of the storage-permeability under the control of lithotypes based on the nuclear magnetic resonance. Geol J China Univ 22(3):543-548

Lu J, Zhang XY (1986) Discovery of tertiary sphagnum coal in Jinsuo basin, Yunnan province and its significance. Sci Bull 22:46-49

Lu J, Zhang XY (1988) Characteristics of sphagnum coal considered as a new genetic type of coal. Int J Coal Geol 11(2):191-203

Luo YF (2019) Research on the quality control of civil coal and interpretation of national standard. China Coal 45(2):14-18

Luo KL, Ren DY, Xu LR, Dai SF, Cao DY, Feng FJ, Tan JA (2004) Fluorine content and distribution pattern in Chinese coals. Int $\mathrm{J}$ Coal Geol 57(2):143-149

Luo YF, Li WH, Jiang Y, Bai XF (2005) Distribution of sulfur in coals of China. Coal Convers 28(3):14-18

Luo YF, Jiang Y, Liu F (2015) Status and development of standardization of resource conversation and comprehensive utilization of coal. China Coal 3:15-18
Ma QY (2004) Distribution features of coking coal resources in China. Coal Sci Technol 32(3):63-66

Mao JH, Xu HL (1996) Resources prediction and evaluation of Chinese coals. Science Press, Beijing

Mao WH, Zhuang XG, Zhou JB, Ruan CW, Lei GM (2011a) Application of coal facies parameters in sequence stratigraphic division of coal seams: with Zhangnanxi coal district, Junggar basin as example. Coal Geol Exp 39(1):6-10

Mao ZQ, Zhao Y, Sun W, Cai WY, Lu AY, Zhao YC (2011b) Identification on the type of coal rank by using geophysical well logging data. J China Coal Soc 36(5):766-771

Qi M, Rong X, Tang DZ, Xia J, Monika W (1994) Petrographic and geochemical characterization of pale and dark brown coal from Yunnan province, China. Int J Coal Geol 25(1):65-92

Qin Y (1994) Micropetrology and structural evolution of high-rank coals in P. R. CHI. China University of Mining and Technology Press, Xuzhou

Qin JZ (2005) Hydrocarbon source rocks in China. Science Press, Beijing

Qin Y (2012) Advances and reviews on coalbed methane reservoir formation in China. Geol J China Univ 18(3):405-418

Qin ZH (2017) Theory of coal embedded structure model. J China Univ Min Technol 46(5):939-958

Qin SF, Zhong NN, Qin Y, Ren DY (1996) Classification of organic maceral in carbonates. Pet Geol Exp 3:325-330

Qin KZ, Guo SH, Li SY (1998a) New concept on coal structure and new consideration for the generation mechanism of oil from coal. Chin Sci Bull 43(24):2025-2035

Qin Y, Jiang B, Zeng Y (1998b) Jumpy evolution of EPR response of Chinese high-rank coals and its implication to geochemistry. Ser D Earth Sci 41(3):230-234

Qin Y, Fu XH, Ye JP, Tang SH, Lin DY, Li GZ (1999) Geological characteristics and mechanism of controlling gas in petrophysical factors of coal reservoirs in China. China Coalbed Methane 2:29-33

Qin YH, Qin Y, Li ZF, Gao F (2006) Categories and constituents of high-quality environmentally friendly steam coal in China. J Energy Technol Manag 6:83-85

Qin ZH, Gong T, Li XS, Hou CL, Zhang D, Sun H (2008) TEM analysis of coal extraction and coal inbuilt state structural model. J China Univ Min Technol 37(4):443-449

Qin Y, Wang WF, Cheng AG, Liu XH, Zhao JL (2009) Study of oreforming potential of gallium in coal for the first group of state programmed mining districts. Coal Geol China 21(1):17-21

Qin ZH, Li XS, Chen J, Zhang LY, Hou CL, Gong T (2010) Origin and formation mechanism of coal caking property. J China Univ Min Technol 39(1):64-69

Qin Y, Moore TA, Shen J, Yang ZB, Shen YL, Wang G (2017) Resources and geology of coalbed methane in China: a review. Int Geol Rev 60:1-36

Qu ZH, Jiang B, Wang JL, Dou XZ, Li M (2012) Evolution of textures and stress-strain environments of tectonically-deformed coals. Geol J China Univ 18(3):453-459

Qu ZH, Jiang B, Wang JL, Li M (2015) Reaction of macromolecular structure of coals of various ranks to stress-strain environment. J China Univ Min Technol 44(4):64-71

Ren DY, Dai SF (2009) Potential coexisting and associated mineral resources in coal and coal-bearing strata-an issue should pay close attention to. Coal Geol China 21(10):1-4

Ren DY, Tang YG, Lei JJ (1994) Study on regulations of sulfur occurrence and pyrite magnetism of late Permian coals in Southwest China. J China Univ Min Technol 2:64-73

Ren DY, Zhao FH, Zhang JY, Xu DW (1999) Type of enrichment for hazardous minor and trace elements in coal. Earth Sci Front (China University of Geosciences, Beijing) 6(s1):17-22 
Ren DY, Zhao FH, Dai SF, Zhang JY, Luo KL (2006) Trace element geochemistry of coal. Science Press, Beijing

Ren ZL, Zhang S, Gao SL, Cui JP, Gao YY, Xiao H (2007) Tectonic thermal history and its significance on the formation of oil and gas accumulation and mineral deposit in Ordos Basin. Sci China D Earth Sci 50(2):27-38

Selinus O, Alloway B, Centeno JA, Finkelman RB, Fuge R, Lundh U, Smedley P (2005) Essentials of medical geology. Elsevier, Burlington

Shao LY, Jones T, Gayer R, Dai SF, Li SS, Jiang YF, Zhang PF (2003) Petrology and geochemistry of the high-sulfur coals from the Upper Permian carbonate coal measures in the Heshan Coalfield, southern China. Int J Coal Geol 55(1):1-26

Shao LY, Lu J, Wang H, Zhang PF (2009) Development of coal measures Sequence Stratigraphy in China. Acta Sedimentol Sin 27(5):904-914

Shao LY, Wang XT, Lu J, Wang DD, Hou HH (2017) A reappraisal on development and prospect of coal sedimentology in China. Acta Sedimentol Sin 35(5):1016-1031

Shu XQ, Xu XC (1998) Review on research of less combustible constituents in coals. Coal Convers 3:19-23

Song XX, Wang SQ, Tang YG, Li W, Wang SQ, Yang XM (2013) Fractal characteristics of adsorption pores of tectonic coal from Zhongliangshan Southern coalmine. J China Coal Soc 38(01):134-139

Song XX, Wang SQ, Tang YG, Li W, Zeng FG, Xiang JH (2014) Pore structure in tectonically deformed coals by small angle X-ray scattering. J China Coal Soc 39(4):719-724

Stach E, Mackowsky MT, TeichmÜller M (1982) Stach's textbook of coal petrology. GebrÜder borntraeger, Berlin Stuttgart

Su XB (1988) Sulfur in coal of Longtan Formation in Late Permian, Nantong Mining Area, Liangshan, Sichuan. Ph.D thesis, China University of Mining and Technology

Su XB, Fang WD (1998) Permeability of coalbed methane reservoir and its grade and classification. J Jiaozuo Inst Technol 2:13-18

Su CG, Zhu JG, Meng WC, Jiang B, Wang TP, Wang WX (2005) Rediscussion of coal-formed oil mechanism in Turpan-Hami basin. Xinjiang Pet Geol 26(4):453-458

Sun XG (2001) A study of chemical structure in "barkinite" using time-of-flight secondary ion mass spectrometry. Int J Coal Geol 47(1):1-8

Sun XG (2002) The optical features and hydrocarbon-generating model of "barkinite" from Late Upper Permian coals in South China. Int J Coal Geol 51:251-261

Sun YZ, Horsfield B (2005) Comparison of the geochemical characteristics of "barkinite" and other macerals from the Dahe Mine, South China. Energy Exp Exploitation 23(6):475-494

Sun JX, Jervis RE (1986) Trace elements in coal and their distribution in combustion process. Sci China Phys Mech Astron 12:57-64

Sun QL, Li W, Li BQ (2002) Pyrolysis of Shenmu coal macerals and kinetics analysis. J Chem Ind Eng (China) 53(11):1122-1127

Sun QL, Li W, Chen HK, Li BQ (2004) Molecular modeling of coal macerals by using quantum chemistry. J Fuel Chem Technol 32(3):282-286

Sun YZ, Zhao CL, Li YH, Wang JX, Zhang JY, Jin Z, Lin MY, Kalkreuth W (2013) Further information of the associated Li deposits in the no. 6 coal seam at Jungar coalfield, Inner Mongolia, Northern China. Acta Geol Sin English Ed 87(4):1097-1108

Sun YZ, Zhao CL, Li YH (2014) Minimum mining grade of the selected trace elements in Chinese coal. J China Coal Soc 39(4):744-748

Tang YG (1993) Study on the mineralization of pyrite in the Late Permian coals in Sichuan and its magnetic properties. Ph.D thesis, China University of Mining and Technology
Tang XY, Huang WH (2004) Trace elements in Chinese coal. Commercial Press, Beijing

Tang YG, Ren DY, Liu QF, Yao GH, Gan ZJ (1996) Relationship between the coal-forming environment and sulfur in the Late Permian coal of Sichuan, China. Acta Sedimentol Sin 4:161-167

Tang DZ, Yang Q, Zhou CG, Kang XD, Liu DM, Huang WH (2001) Genetic relationships between swamp microenvironment and sulfur distribution of the Late Paleozoic coals in North China. Sci China (Series D Earth Sci) 6:555-565

Tang YG, Zhang HY, Peng SP, Zheng XG, Zhang X (2002) Study on occurrence mode and geological genesis of organic sulfur in coal in China. J Shandong Univ Sci Technol (Nat Sci) 21(4):1-4

Tang SH, Qin Y, Jiang YF (2006) Geological study on clean coal in China. Geological Publishing House, Beijing

Tang YG, Guo YN, Wang SQ (2011) The Chinese typical coal typebark coal: a review. Bull Natl Nat Sci Found China 3:154-163

Tang YG, Wang HS, Cheng AG, Xie XC, Zhang ZX, Yang ST, Zhang QH, Wang SQ (2012) The evaluation and distribution to coal quality grade of Shanxi Province, China. Ann Meet Soc Organ Pet 29:49-51

Tang YG, Cheng AG, Wang HS, Wang SQ, Zhang ZX, Xie XC, Zhang QH, Wang C, Jia L (2013a) Coal quality characteristic analysis of Taiyuan formation and Shanxi formation in Shanxi Province. Coal Sci Technol 41(7):10-15

Tang YG, Wang SQ, Yang ST, Guo MT, Gao WC, Lu XK, Wei Q, Han SC, Guo X, He X (2013b) The distribution of coal with different quality in China, the fourth part of evaluation report on the potential of coal resources in China. Eva Rep (in Chinese)

Tang DZ, Deng CM, Meng YJ, Li ZP, Xu H, Tao S, Li S (2015a) Characteristics and control mechanisms of coalbed permeability change in various gas production stages. Pet Sci 12(4):684-691

Tang YG, He X, Cheng AG, Li WW, Deng XJ, Wei Q, Li L (2015b) Occurrence and sedimentary control of sulfur in coals of China. J China Coal Soc 40(9):1977-1988

Tang YG, Guo X, Xie Q, Finkelman RB, Han SC, Haun BB (2018a) Petrological characteristics and trace elements partitioning of gasification residues from slagging entrained-flow gasifiers in Ningdong, China. Energy Fuels 32(3):3052-3067

Tang YG, Huan X, Lan CY, Xu MX (2018b) Effects of coal rank and high organic sulfur on the structure and optical properties of coal-based graphene quantum dots. Acta Geol Sin English Ed 92:1218-1230

Tao MX (2005) Current status and development trend of coalbed methane geochemistry. Progress Nat Sci 6:648-652

Taylor GH (1998) The organic petrology. Gebrüder Borntraeger, Berlin

Tu JQ, Chen JP, Zhang DJ, Cheng KM, Chen JJ, Yang ZM (2012) A petrographic classification of macerals in lacustrine carbonate source rocks and their organic petrological characteristics: a case study on Jiuxi basin, NW China. Acta Pet Sin 28(3):917-926

Wang CG (1998) Geochemistry of Jurassic coal-formed hydrocarbon in Turpan-Hami Basin. Science Press, Beijing

Wang T, Cao ZY (1990) Protecting scarce coals to develop Wangjialing mine. Coal Eng 2:11-15

Wang FY, Fu JM, Liu DH (1993a) Characteristics and classification of organic matter of coal and terrigenous organic matter source rocks. Chin Sci Bull 38(23):2164-2168

Wang FY, Fu JM, Liu DH, Shi GS, Lei JJ (1993b) The significance of ultramicro lipids in vitrinite of coal and hydrocarbon source rocks. Chin Sci Bull 38(2):151

Wang SJ, Yu B, Zhang J, Tang JX (1997) Coal forming plants of Tertiary Baipaomei coal in Yunnan and its genes. J China Coal Soc 1:10-14

Wang WF, Qin Y, Song DY (2003) Study on the mobility and release of trace elements in coal-fired powerplant. Acta Sci Circum 6:748-752 
Wang WF, Qin Y, Fu XM (2005a) Study on potential comprehensive pollution index and cleanliness grade of hazardous elements in coal. Nat Sci Progress 18(8):973-980

Wang WF, Qin Y, Song DY, Sang SX, Jiang B, Zhu YM, Fu XH (2005b) Element geochemistry and cleaning potential of the No. 11 coal seam from Antaibao mining district. Sci China (Ser D Earth Sci) 12:2142-2154

Wang EY, Yin QC, Li FL (2008) Research state and its development trends of structure coal. J Henan Polytech Univ (Natl Sci) 3:278-281

Wang SQ, Tang YG, Schobert HH, Guo YN, Su YF (2013) Petrology and structural studies in liquefaction reactions of Late Permian coals from Southern China. Fuel 107:518-524

Wang SQ, Tang YG, Schobert HH, Jiang D, Guo X, Huang F, Guo YN, Su YF (2014) Chemical compositional and structural characteristics of Late Permian bark coals from Southern China. Fuel 126:116-121

Wang SQ, Tang YG, Schobert HH, Jiang D, Sun YB, Guo YN, Su YF, Yang SP (2015) Application and thermal properties of hydrogen-rich bark coal. Fuel 162:121-127

Wang CJ, Du JG, Liang YH (2017a) Study on influencing factors of permeability of coalbed methane reservoir. Min Saf Environ Prot 44(6):83-87

Wang Q, Dong ZL, Zhang B, Zhang PQ, Hou QL, Wang XY (2017b) Study on coal metamorphic degree under the synergistic effect of geothermal anomaly and magmatic rock. China Coal 12:54-58

Wang SQ, Chen H, Zhang XM, Sha YM (2017c) HRTEM characteristics of different ranks with coals rich in barkinite. Coal Technol 36(12):266-268

Wang SQ, Tang YG, Schobert HH, Jiang YF, Yang ZD, Zhang XM (2018a) Petrologic and organic geochemical characteristics of Late Permian bark coal in Mingshan coalmine, Southern China. Mar Pet Geol 93:205-217

Wang SQ, Tang YG, Schobert HH (2018b) The properties and conversions of bark coal. Science Press, Beijing

Wang SQ, Chen H, Liu PH, Sha YM, Lin YH (2018c) HRTEM image changes on heating and thermogravimetric characteristics of barkinite. J Fuel Chem Technol 2:2

Wang YF, Tang YG, Liu SQ, Wang YG, Finkelman RB, Wang BL, Guo X (2018d) Behavior of trace elements and mineral transformations in the super-high organic sulfur Ganhe coal during gasification. Fuel Process Technol 177:140-151

Wang YF, Tang YG, Guo X, Xie Q, Finkelman RB, Li PY, Chen PX (2019) Fate of potentially hazardous trace elements during the entrained-flow coal gasification processes in China. Sci Total Environ 668:854-866

Wei CW, Li BQ, Li W, Chen HK, Wang ZZ (2003) Effect of macerals on the properties of coal water slurry. J Fuel Chem Technol 31(5):415-419

Wei Q, Tang YG, Li WW (2015) Research advances on organic sulfur structures in coal. J China Coal Soc 40(8):1911-1923

Wei MM, Ju YW, Hou QL, Wang GC, Yu LY, Zhang WL, Li XS (2017) A new parameter as an indicator of the degree of deformation of coals. J Earth Sci English Ed 28(2):358-366

Wu CR (1995) Research on coal petrology properties and metamorphism of Early-Mid Jurassic coal in Northwest China. Coal Industry Publishing House, Beijing

Wu CL, Yang Q, Liu G, Zhou JY, Liang XB (1997) Principles and methods of thermodynamics foranalysis of coal metamorphism. J China Coal Soc 3:225-229

Wu DS, Zheng BS, Tang XY, Wang Y, Liu XB, Hu J, Finkleman RB (2005) Content and distribution of fluorine in Chinese coals. Environ Sci 28(1):7-11

Xia XH (2009) Migration and its environmental effect of deleterious elements in coal during direct liquefaction. Ph.D thesis, China University of Mining and Technology
Xia XH, Qin Y, Wang WF, Wu YY (2007) Advances on study of essential coal characteristics from direct liquefaction. China Min Mag 5:87-89

Xiao XM, Jin KL (1990a) A petrographic classification of macerals in terrestrial hydrocarbon source rocks in china and their organic petrological characteristics. Acta Sedimentol Sin 3:22-34

Xiao XM, Jin KL (1990b) Microscopic composition of DTA and its relationship with hydrocarbon generation. Coal Geol Exp 3:19-25

Xie KC (1992) Systematical understanding and research on coal structure and reactivity: the structure aspects. Coal Convers $1: 24-30$

Xie KC (2002) Coal structure and its reactivity. Science Press, Beijing

Xie KC (2014a) Clean and efficient conversions of coal. Science Press, Beijing

Xie KC (2014b) Strategic research on clean, efficient, sustainable development and utilization of coal in China. Science Press, Beijing

Xie GX, Li XY, Zhuang J (2001) Classification, forming conditions and characteristic of sclerotia-algal coals, China. Coal Geol Exp 3:10-13

Xu ZG, Yan SH (2003) Review of study on gasification characteristic of macerals. Coal Convers 26(3):11-15

Yang Q (1979) China coalfield geology. Coal Industry Publishing House, Beijing

Yang Q (1987) Coal geology progress. Science Press, Beijing

Yang Q (1996a) The coal metamorphism in China. Coal Industry Publishing House, Beijing

Yang YK (1996b) Atlas for coal petrography of China. China University of Mining and Technology Press, Xuzhou

Yang Q, Pan ZG, Tang DZ, Liao LB, Ma ZS, Shi NC (1994) Study of coal structure using STM and AFM. Chin Sci Bull 11:941-944

Yang ST, Tang YG, Xie XC, Yang FJ (2011) Research on clean potential assessment of coal resources. Clean Coal Technol 17(1):5-8

Yao ZK (1988) Tectonic evolution of coal-forming processes in China and uranium mineralization in coalbeds. Geotectonica et Metallogenia 3:5-16

Yao SP, Jin KL (1995) A New method of studying sedimentary organic facies by means of macerals'dual nature. Geol Rev 6:525-532

Yao SP, Zhang JR, Jin KL (1997) Detection of solid particles or kerogen in crude oil and its geological significance. Sci China (Ser D) 1:59-64

Ye DM (2004) The relationship between fluorescence intensity of vitrinite and petrographic parameters of coal. Coal Geol Exp 32(1):4-5

Yuan SW (1999) A review on coal quality in China. Coal Industry Publishing House, Beijing

Yuan L, Liu QY, Yu L (2017) Research on structure evolution of high-rank coals in Feng County, Shaanxi. China Coal 10:39-44

Zeng Y (2001) Special coal types in Western China and their exploitation and utilization. J China Coal Soc 26(4):337-340

Zeng FG, Xie KC (2004) Theoretical system and methodology of coal structural chemistry. J China Coal Soc 29(4):443-447

Zeng FG, Jiang WP, Xie KC (2005) Original innovations of clean coal technology-progress of coal molecular engineering and its key problems. J China Coal Soc Progress Nat Sci 4:15-21

Zhang PF (1997) Coal bearing deposits and coal formed oil in Turpan Hami Basin, Northwestern China. Coal Industry Publishing House, Beijing

Zhang H (2001) Genetical type of pores in coal reservoir and its research significance. J China Coal Soc 26(1):40-44 
Zhang YT (2015) Preparation, modification, and application of coalbased-graphene. Ph.D thesis, Xi' an University of Science and Technology

Zhang H, Li XY (2004) Application of scanning electron microscope in coal petrology. J Chin Electron Microsc Soc 23(4):467

Zhang Q, Yang XL (1999) Isothermal adsorption of coals on methane under equilibrium moisture. J China Coal Soc 24(6):566-570

Zhang J, Yuan JW, Xu YQ (1998) Pyrolysis mechanism of macerals at a low heating rate. $J$ Fuel Chem Technol 1:46-50

Zhang J, Han CL, Wang XH, Xu YQ (2002) Experimental study of drop-tube furnace on combustion characteristics of maceral concentrates. J Combust Sci Technol 8(5):403-406

Zhang JY, Zheng CG, Ren DY, Zhang YG, Guo L (2003) On trace elements in circulating fluidized bed combustion of coal. J Combust Sci Technol 1:64-67

Zhang JY, Zhao YC, Ding F (2007) Preliminary study of trace element emissions and control during coal combustion. Front Energy Power Eng Chin 1(3):273-279

Zhang LS, Guan YB, Li HM, Zhang GB, Zhao P, Li S, Zheng J, Cui S (2010) Variety regularity of metamorphic coal of Longdong coalfield in Xingtaiby X-ray diffraction method. Coal Geol Exp $38(2): 1-4$

Zhang XB, Wang W, Zhang YG, Gao F, Huan X (2016) Oriented growth mechanism of tectonic coal microcrystal. J China Coal Soc 41(3):712-718

Zhao ZG (2002) Research on rare-earth elements geochemistry of coal-bearing strata. Coal Industry Publishing House, Beijing

Zhao SQ, Wang FY, Dong MS (1994) Discussion on the "sedimentary environment-type of coal-forming-characteristic of coal quality" rough genetic model: environment and coal facies. Acta Sedimentol Sin 1:32-39
Zhao FH, Ren DY, Zheng BS, Hu TD, Liu T (1998) Modes of occurrence of arsenic in high-arsenic coal by extended X-ray absorption fine structure spectroscopy. Chin Sci Bull 43(19):1660-1663

Zhao QJ, Tang YG, Li WW, Wang SQ, Deng XJ, Xu XL (2014a) Compositional characteristics of sulfur-containing compounds in high sulfur coals. Energy Explor Exploit 32(2):301-316

Zhou SY (1985) Applied coal petrology. Metallurgical Industry Press, Beijing

Zhao W, Zhang XQ, Zhou AN (2014b) Flotation separation of Shenfu coal macerals and low temperature pyrolysis characteristics of different maceral concentrate. $J$ Fuel Chem Technol 42(5):527-533

Zheng BS (1991) Selenium enrichment regularity and genesis in selenium-rich rock layers in western Hubei. Bull Miner Pet Geochem 10(3):129-131

Zheng YS, Zhijun W (1992) The Char types of macerals and their combustion modes. J China Univ Min Technol 3:40-48

Zheng BS, Ding ZH, Huang RG, Zhu JM, Yu XJ, Zhang AM, Zhou DX, Mao DJ, Su HC (1999) Issues of health and disease relating to coal use in southwestern China. Int $\mathrm{J}$ Coal Geol 40(2-3):119-132

Zhong NN, Smyth M (1997) Striking liptinitic bark remains peculiar to some Late Permian Chinese coals. Int J Coal Geol 33:333-349

Zhou YP (1994) Mercury distribution types and existence form in anthracite of Linchang mining area. Coal Geol Exp 3:17-22

Zhou CG, Yang Q, Kang XD, Tang DZ, Liu DM (1999) Development on the study of sulfur in coal. Coal Geol Exp 1:16-20

Zhu JM, Liang XB, Ling HW, Wang MS, Wang FS, Liu SR (2003) Advances in studying occurrence modes of selenium in environment. Bull Miner Pet Geochem 1:75-81 